\title{
MEDICINE
}

\section{ЗВ'ЯЗОК МІЖ ПОКАЗНИКАМИ ТІЛОБУДОВИ І МІНЕРАЛЬНОЇ ЩІЛЬНОСТІ КІСТКОВОЇ ТКАНИНИ У ПРАКТИЧНО ЗДОРОВИХ ЧОЛОВІКІВ ТА ПАЦІЕНТІВ ІЗ ТРАВМОЮ ХРЕБТА Й СПИННОГО МОЗКУ}

${ }^{l}$ Бистрицька М. А., к. мед. н.

${ }^{2}$ Балацька Н. І., д. мед. н., дочент

${ }^{1}$ Мусіснко А. C.

${ }^{3}$ Климчук Л. Ф.

${ }^{1}$ ДУ «Інститут геронтологї імені Д. Ф. Чеботарьова НАМН України».

${ }^{2}$ ПвНЗ «Киїський медичний університет»

${ }^{3}$ Національна медична академія післядипломної освіти імені П. Л. Шупика»

DOI: https://doi.org/ 10.31435/rsglobal_ws/30092018/6133

\section{ARTICLE INFO}

Received: 10 July 2018

Accepted: 21 September 2018

Published: 30 September 2018

\section{KEYWORDS}

spinal cord injury,

bone mineral density,

lean mass,

fat mass.

\begin{abstract}
The purpose of the study was evaluating the peculiarity of bone mineral density (BMD) and body composition in patients with spinal cord injury (SCI). 51 men with SCI were enrolled to the study. The comparison group consists of 51 healthy men which were standardized by age and body weight. The study revealed in patients with SCI significantly higher rate of osteoporosis $(84.31 \%)$ and sarcopenia (43.14\%) in comparison with healthy men $(1.96 \%$ and $25.49 \%$ accordingly). In healthy men the correlation analysis revealed the wide-ranging influence of body composition on lower extremities BMD. Thus, femur neck BMD is determined by the lean mass of upper extremities $(r=0.33, p<0.05)$, lower extremities $(r=0.38, p<0.05)$, trunk $(r=0.41, p<0.05)$ and total body $(\mathrm{r}=0.43, \mathrm{p}<0.05)$. Hip BMD depends on the lean mass of trunk $(\mathrm{r}=0.36$, $\mathrm{p}<0.05)$ and total body $(\mathrm{r}=0.34, \mathrm{p}<0.05)$. Lower extremities BMD correlates with lean mass of trunk $(r=0.33, p<0.05)$ and lower extremities $(r=0.32$, $\mathrm{p}<0.05)$. In men with SCI it was found the correlation between femur neck BMD and trunk lean mass $(\mathrm{r}=0.30, \mathrm{p}<0.05)$; hip BMD correlates with lean mass of trunk $(r=0.31, p<0.05)$ and lower extremities $(r=0.35$, $p<0.05)$; lower extremities BMD correlates with lean mass of trunk $(r=0.41, p<0.05)$ and lower extremities $(r=0.32, \mathrm{p}<0.05)$. Consequently, our study showed the influence of lean body mass on lower extremities BMD in both groups, which should be taken into account during managements of patients with SCI.
\end{abstract}

Citation: Бистрицька М. А., Балацька Н. І., Мусієнко А. С., Климчук Л. Ф. (2018) Zviazok Mizh Pokaznykamy Tilobudovy i Mineralnoi Shchilnosti Kistkovoi Tkanyny u Praktychno Zdorovykh Cholovikiv ta Patsiientiv iz Travmoiu Khrebta y Spynnoho Mozku. World Science. 9(37). doi: 10.31435/rsglobal_ws/30092018/6133

Copyright: (C) 2018 Бистрицька М. А., Балацька Н. І., Мусієнко А. С., Климчук Л. Ф. This is an open-access article distributed under the terms of the Creative Commons Attribution License (CC BY). The use, distribution or reproduction in other forums is permitted, provided the original author(s) or licensor are credited and that the original publication in this journal is cited, in accordance with accepted academic practice. No use, distribution or reproduction is permitted which does not comply with these terms.

Збільшення тривалості життя пацієнтів із травмою хребта та спинного мозку (ТХCM) призводить до збільшення частоти пізніх ускладнень, зокрема остеопорозу. ТХСМ супроводжується глибокими змінами тілобудови, втратою м'язової та кісткової тканини. Атрофічні зміни м’язів у пацієнтів із тетра- та параплегією описані в багатьох роботах, проте 
механізми цих змін достеменно не вивченні [1]. На сьогодні з'являється все більше даних про перехресні чинники втрати кісткової та м'язової маси після ТХСМ, що привертає увагу до вивчення показників тілобудови цієї категорії пацієнтів [2]. Двохфотонна рентгенівська абсорбціометрія дозволяє кількісно оцінити показники кісткової, жирової та знежиреної маси, утвореної переважно скелетними м'язами та внутрішніми органами. В 1998 році Richard Baumgartner описав синдром «саркопенії» - зниження м'язової маси й сили та визначив критерії його встановлення - зниження індексу апендикулярної знежиреної маси менше $>7,26$ для чоловіків та $>5,67$ кг/ $\mathrm{M}^{2}$ - для жінок[3]. Хоча первинно цей термін описував тільки вікасоційовані зміни м'язової тканини, сьогодні все частіше в літературі він зустрічається при втраті м'язової маси вторинного генезу. При неврологічній патології застосування цього терміну викликає обгрунтовані протиріччя, оскільки саркопенія це зниження маси, сили та функції м'язів, а у випадку неврологічної патології порушення функції м'язів обумовлені іншими факторами [1]. Тим не менше, в сучасній літературі публікуються результати вивчення саркопенії у пацієнтів із ТХСМ [1,4], проте досліджень, присвячених зв'язкам між м'язовою та кістковою системою у пацієнтів із ТХСМ не знайдено.

Метою дослідження стало вивчення мінеральної щільності кісткової тканини, жирової, знежиреної маси та зв'язку між ними в пацієнтів із ТХСМ з повним пошкодженням спинного мозку.

Матеріал і методи. У відділі клінічної фізіології та патології опорно-рухового апарату ДУ «Інститут геронтології імені Д. Ф. ЧеботарьоваНАМН України» було проведено визначення показників кісткової тканини та тілобудови у 51 пацієнта із ТХСМ. Усі пацієнти були чоловічої статі. Групу порівняння склав 51 практично здоровий чоловік відповідного віку. Пацієнти були стандартизовані за віком та масою тіла (табл. 1).

Таблиця 1. Характеристика обстежених пацієнтів із ТХСМ та осіб групи порівняння.

\begin{tabular}{|c|c|c|c|}
\hline Групи/Показники & Група порівняння & Пацієнти із ТХСМ & $\mathrm{p}$ \\
\hline Вік, роки & $29,52 \pm 8,75$ & $29,51 \pm 8,66$ & 0,94 \\
\hline Зріст, м & $1,76 \pm 0,07$ & $1,78 \pm 0,07$ & 0,96 \\
\hline Маса, кг & $70,10 \pm 9,23$ & $69,92 \pm 9,38$ & 0,91 \\
\hline IMТ, кг/м ${ }^{2}$ & $22,56 \pm 3,01$ & $22,00 \pm 2,86$ & 0,73 \\
\hline
\end{tabular}

Примітка. Дані подані у вигляді $M \pm S D$

У дослідження включали чоловіків від 18 до 50 років 3 діагнозом ТХСМ, підтвердженим методами нейровізуалізації (КТ або МРТ) 3 тривалістю посттравматичного періоду від 1 до 7 років 3 пошкодженням спинного мозку на рівні шийного, грудного та поперекового відділів хребта з тетра- та параплегією або глибоким нижнім парапарезом, що виключає можливість стояння та ходи (ступінь пошкодження спинного мозку згідно шкали пошкодження Американської асоціації травми спинного мозку (AIS) - A, В). Обов’язковою умовою включення в дослідження була наявність добровільної інформованої згоди пацієнта. У дослідження не включали пацієнтів з соматичною патологією у декомпенсованому стані, з будь якими захворюваннями 3 відомим впливом на кісткову тканину та пацієнтів 3 вираженою спастичністю та гетеротопічною осифікацією, яка заважає проведенню та оцінці результатів двохфотонної рентгенівської абсорбціометрії. Середня тривалість посттравматичного періоду склала $2,17 \pm 1,41$ років.

Методи дослідження. Мінеральну щільність кісткової тканини (МЩКТ), показники знежиреної та жирової маси визначали за допомогою двохфотонної рентгенівської абсорбціометрії (ДРА) на приладі «Prodigy, GEHC Lunar», Мадісон, США, 2005). Проводили дослідження таких ділянок скелету: поперековий відділ хребта $\left(\mathrm{L}_{1}-\mathrm{L}_{4}\right)$, проксимальний відділ стегнової кістки, шийка стегнової кістки, дистальний відділ кісток передпліччя та весь скелет.

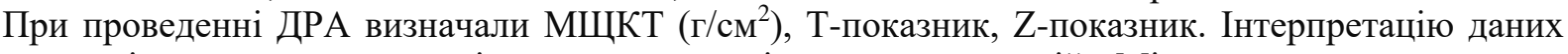
рентгенівської денситометрії проводили згідно рекомендацій Міжнародного товариства клінічної денситометрії (International society for clinical densitometry) [5]. Для чоловіків молодших 50 років оцінку проводили за Z-показником на рівні поперекового відділу хребта, проксимального відділу стегнової кістки або шийки стегнової кістки (найнижчий показник). Значення Z-показника > -2 вважали в межах вікової норми, значення Z-показника $<-2$ вважали нижче референтних значень для відповідного віку, а МЩКТ оцінювалась як низька. Пацієнтам з низькою МЩКТ встановлювали діагноз вторинний остеопороз індукований травмою хребта 
та спинного мозку. Серед показників тілобудови оцінювали жирову масу та знежирену масу всього тіла й апендикулярну знежирену масу (знежирена маса кінцівок).

Статистичний аналіз проводили із застосуванням програм Statistica 10, MEDCALC. Нормальність розподілу визначали за критерієм Шапіро-Уілка. Різницю показників між групами та підгрупами встановлювали за допомогою однофакторного дисперсійного аналізу ANOVA, критерію Стьюдента для незалежних вибірок та критерію Манна-Уітні. Регресійний аналіз показників МЩКТ та віку й антропометричних даних виконаний з використанням лінійної регресії та кореляції Спірмена при непараметричному розподілі. Відмінності розподілу вибірок оцінювали за допомогою критерію $\chi^{2}$ тест. Результати подані як $\mathrm{M} \pm \mathrm{SD}$. Різницю показників вважали вірогідною при $\mathrm{p}<0,05$.

Результати дослідження. У чоловіків із ТХСМ частота остеопорозу була достовірно вищою, ніж у осіб групи порівняння $\left(\chi_{\mathrm{c}}^{2}=24,5\right.$, ДІ: $\left.26,04-54,87, \mathrm{p}<0,0001\right)$. Так, серед чоловіків із ТХСМ остеопороз реєструвався у $43,14 \%$, а у осіб групи порівняння низька МЩКТ була зареєстрована тільки у 1 пацієнта, що склало $1,96 \%$.

У пацієнтів із ТХСМ показники МЩКТ були вірогідно нижчими на рівні всіх обстежених ділянок (рис. 1).

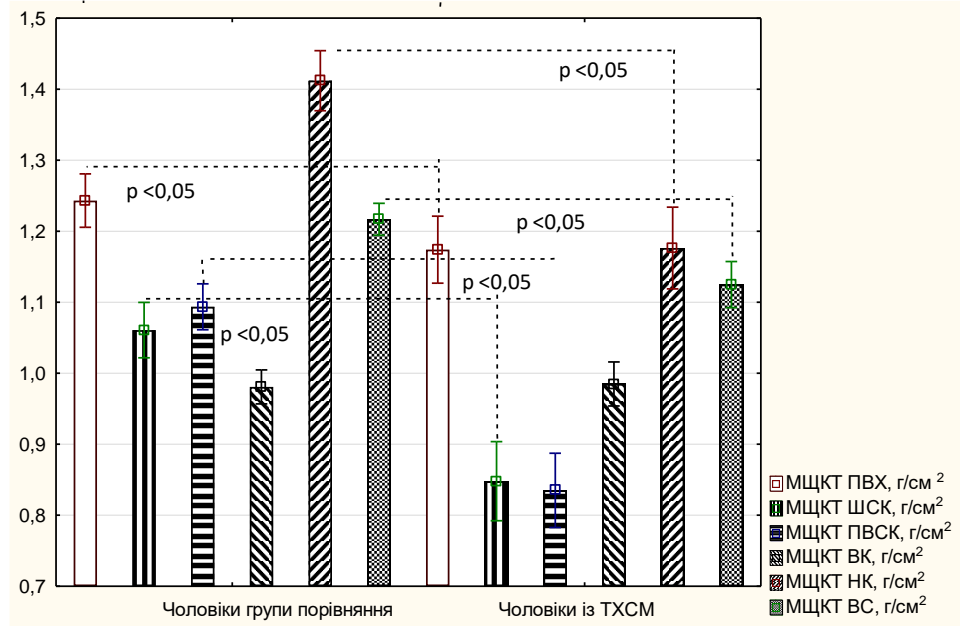

Рис. 1. Показники МЩКТ у чоловіків із ТХСМ та чоловіків групи порівняння.

Примітка. ШСК - шийка стегнової кістки, ПВСК - проксимальний відділ стегнової кістки, ВК - верхні кінцівки, $Н К$ - нижні кінцівки, ВС-весь скелет.

Найбільші відмінності МЩКТ реєстрували на рівні шийки (20,07\%), проксимального відділу $(23,64 \%)$ стегнової кістки та нижніх кінцівок $(16,70 \%)$, що обумовлено відсутністю осьового навантаження у пацієнтів з пара- та тетраплегією.

Аналіз МЩКТ у пацієнтів 3 пара- та тетраплегією не виявив вірогідної різниці показників на рівні шийки та проксимального відділу стегнової кістки, проте МЩКТ на рівні нижніх кінцівок $(1,230 \pm 0,204$ та $1,078 \pm 0,172$ г/см², $\mathbf{p}<0,05)$ та всього скелету $(1,158 \pm 0,109$ та $\left.1,064 \pm 0,104 \mathrm{r} / \mathrm{cm}^{2}, \mathrm{p}<0,05\right)$ була вірогідно нижчою у осіб з тетраплегією. Отримані результати, на нашу думку обумовлені, різними можливостями вертикалізації. Пацієнти 3 тетраплегією в перші роки після травми мають вегетативні порушення, зокрема ортостатичну гіпотензію, що обмежує перебування у вертикальному положенні в рамках тренувань (стояння у вертикалізаторі). Крім того, вертикалізація пацієнтів 3 тетраплегією технічно складніша i вимагає допомоги сторонніх осіб.

Проведені дослідження встановили залежність між тривалістю посттравматичного періоду та МЩКТ, зокрема існує вірогідний негативний кореляційний зв'язок між МЩКТ та тривалістю посттравматичного періоду на рівні шийки стегнової кістки $(\mathrm{r}=-0,38, \mathrm{p}<0,05)$, проксимального відділу стегнової кістки $(\mathrm{r}=-0,45, \mathrm{p}<0,05)$, нижніх кінцівок $(\mathrm{r}=-0,44, \mathrm{p}<0,05)$, МЩКТ всього скелету (r=0,36, $\mathrm{p}<0,05)$.

У пацієнтів із ТХСМ не зареєстровано впливу віку на показники МЩКТ на відміну від осіб групи порівняння, в яких отримано вірогідний кореляційний зв'язок малої сили між віком та МЩКТ нижніх кінцівок $(\mathrm{r}=0,31, \mathrm{p}<0,05)$ і МЩКТ всього скелету $(\mathrm{r}=0,33, \mathrm{p}<0,05)$. Проте у пацієнтів із ТХСМ виявлено кореляційний зв'язок між віком настання травми та МЩКТ поперекового відділу хребта $(r=0,32, \mathrm{p}<0,05)$ і всього скелета $(\mathrm{r}=0,30, \mathrm{p}<0,05)$. Тобто, чим в 
старшому віці настала травма, тим вищі показники МЩКТ. На нашу думку подібні результати обумовлені особливостями формування кісткової тканини. Згідно досліджень професора Поворознюка В. В. пік кісткової маси українські чоловіки в середньому досягають в 25-ти річному віці [6].

У пацієнтів із ТХСМ виявлено вплив маси тіла на показники МЩКТ всіх ділянок скелету: на рівні поперекового відділу хребта $(\mathrm{r}=0,52, \mathrm{p}<0,05)$, шийки стегнової кістки $(\mathrm{r}=0,41$, $\mathrm{p}<0,05)$, проксимального відділу стегнової кістки $(\mathrm{r}=0,46, \mathrm{p}<0,05)$, нижніх кінцівок $(\mathrm{r}=0,52$, $\mathrm{p}<0,05)$, всього скелету $(\mathrm{r}=0,57, \mathrm{p}<0,05)$. У чоловіків групи порівняння подібні зв'язки зареєстровані лише на рівні нижніх кінцівок $(\mathrm{r}=0,36, \mathrm{p}<0,05)$ та всього скелету $(\mathrm{r}=0,40, \mathrm{p}<0,05)$. Отримані дані спонукали до більш детального вивчення показників тілобудови та їх впливу на МЩКТ в досліджуваних групах.

Серед пацієнтів із ТХСМ 84,31\% мали саркопенію (значення індексу аппендикулярної знежиреної маси $<7,26$ ) [7]. В групі порівняння саркопенія діагностувалась вірогідно рідше - у $25,49 \%$ осіб $\left(\chi_{\mathrm{c}}^{2}=35,28\right.$, ДІ: 40,63-71,29, $\left.\mathrm{p}<0,0001\right)$.

Порівняльний аналіз результатів обстеження виявив у чоловіків із ТХСМ достовірно нижчі показники знежиреної маси $(47,97 \pm 5,73$ та $53,54 \pm 5,16$ кг, $\mathrm{p}<0,0001)$ й апендикулярної знежиреної маси $(20,20 \pm 3,38$ та $23,97 \pm 4,38$ кг, $<<0,0001)$ на рівні всього тіла, достовірно нижчі показники знежиреної маси на рівні тулуба $(23,89 \pm 2,84$ та $25,15 \pm 2,52$ кг, р<0,05) й нижніх кінцівок $(13,74 \pm 2,61$ та 17,56 $\pm 2,11$ кг, $\mathrm{p}<0,05)$ (рис. 2).

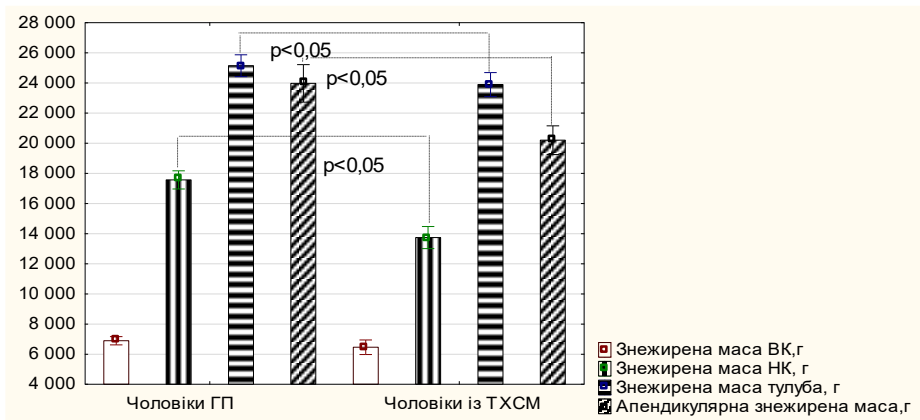

Рис. 2. Показники знежиреної маси у чоловіків із ТХСМ та групи порівняння.

Примітка. ВК - верхні кінцівки, НК - нижні кінцівки.

При порівнянні пацієнтів з пара- та тетраплегією, в останніх отримано достовірно нижчі показники знежиреної маси на рівні верхніх кінцівок $(5,86 \pm 1,37$ та $6,40 \pm 1,70$ кг, $<<0,05)$, тулуба $(22,82 \pm 2,61$ та 24,48 $\pm 2,83$ кг, $\mathrm{p}<0,05)$ та всього тіла $(45,63 \pm 4,70$ та 49,24 $\pm 5,90$ кг, $\mathrm{p}<0,05)$. Вірогідних відмінностей знежиреної маси нижніх кінцівок у цих пацієнтів не знайдено.

При досліджені впливу тривалості посттравматичного періоду на показники знежиреної маси встановлено вірогідний зв'язок між тривалістю посттравматичного періоду та знежиреною масою нижніх кінцівок ( $\mathrm{r}=-0,32, \mathrm{p}<0,05)$, що вказує на прогресуючу втрату м'язів нижніх кінцівок зі збільшенням тривалості посттравматичного періоду.

Вміст жирової маси, навпаки, у пацієнтів із ТХСМ проти групи порівняння був вірогідно вищим, як на рівні нижніх кінцівок $(27,96 \pm 8,16$ та $19,21 \pm 7,94 \%, \mathrm{p}<0,0001)$, так i всього тіла $(24,21 \pm 9,05$ та $19,95 \pm 1,11 \%, \mathrm{p}<0,05)$ і не залежав від тривалості посттравматичного періоду.

Враховуючи те, що пацієнти із ТХСМ найчастіше мають переломи кісток нижніх кінцівок (стегнова та кістки гомілки) [8], досліджували вплив показників тілобудови на МЩКТ шийки, проксимального відділу стегнової кістки та нижніх кінцівок.

Проведений аналіз отриманих даних в досліджуваних групах виявив, що у чоловіків групи порівняння реєструється вірогідний кореляційний зв'язок між МЩКТ шийки стегнової кістки і показником знежиреної маси верхніх кінцівок $(\mathrm{r}=0,33, \mathrm{p}<0,05)$, нижніх кінцівок $(\mathrm{r}=0,38$, $\mathrm{p}<0,05)$, тулуба $(\mathrm{r}=0,41, \mathrm{p}<0,05)$ та всього тіла $(\mathrm{r}=0,43, \mathrm{p}<0,05)$. Якщо врахувати, що знежирена маса представлена переважно м'язовою тканиною, то виявлені кореляційні зв'язки можна пояснити позитивним впливом фізичного навантаження, що призводить до збільшення маси м'язів та МЩКТ. Також виявлено позитивний вплив на МЩКТ проксимального відділу стегнової кістки показників знежиреної маси тулуба $(\mathrm{r}=0,36, \mathrm{p}<0,05)$ та всього тіла $(\mathrm{r}=0,34$, $\mathrm{p}<0,05)$. Мінеральна щільність нижніх кінцівок достовірно корелювала 3 показником знежиреної маси тулуба $(\mathrm{r}=0,33, \mathrm{p}<0,05)$ та нижніх кінцівок $(\mathrm{r}=0,32, \mathrm{p}<0,05)$. Також виявлено прямий кореляційний зв'язок (рис. 3). 
У чоловіків із ТХСМ не виявлено залежності між показниками тілобудови верхніх кінцівок та МЩКТ шийки, проксимального відділу стегнової кістки та МЩКТ нижніх кінцівок. Зареєстровано кореляційний зв'язок низької сили між знежиреною масою тулуба та МЩКТ шийки стегнової кістки $(\mathrm{r}=0,30, \mathrm{p}<0,05)$, проксимального відділу стегнової кістки $(\mathrm{r}=0,31$, $\mathrm{p}<0,05)$ та МЩКТ нижніх кінцівок $(\mathrm{r}=0,41, \mathrm{p}<0,05)$. Також отримано кореляційний зв'язок між знежиреною масою нижніх кінцівок та МЩКТ проксимального відділу стегнової кістки (r=0,35, (рис. 4).

На нашу думку, виявлений вплив знежиреної маси тулуба на МЩКТ нижніх кінцівок обумовлений можливістю пацієнта перебувати у вертикальному положенні (наприклад в коліноупорі), що тренує м’язи тулуба та збільшує показники МЩКТ нижніх кінцівок.

Проведені дослідження виявили прямий вплив жирової маси нижніх кінцівок на МЩКТ нижніх кінцівок лише у пацієнтів із ТХСМ (рис. 3,4$).$

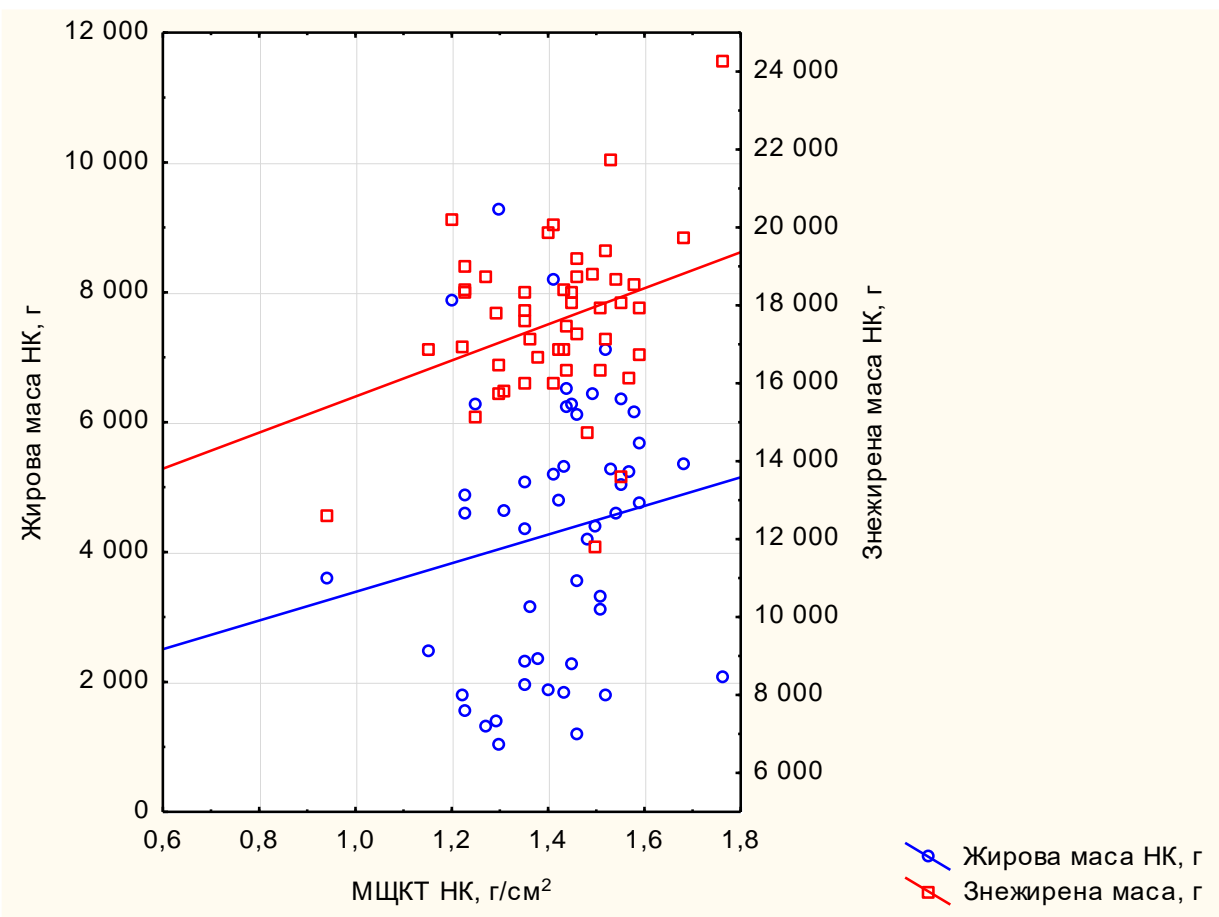

Рис. 3. Вплив жирової $і$ знежиреної маси нижніх кінцівок на показник МЩКТ нижніх кінщівок у паџієнтів групи порівняння.

Примітка. НК - нижні кіниівки. Встановлено достовірний кореляційний зв'язок між показниками МЩКТ НК та знежиреною масою НК ( $r=0,32 ; p<0,05)$, не виявлено впливу жирової маси НК на показники МЩКТ НК $(r=0,16 ; p>0,05)$. 


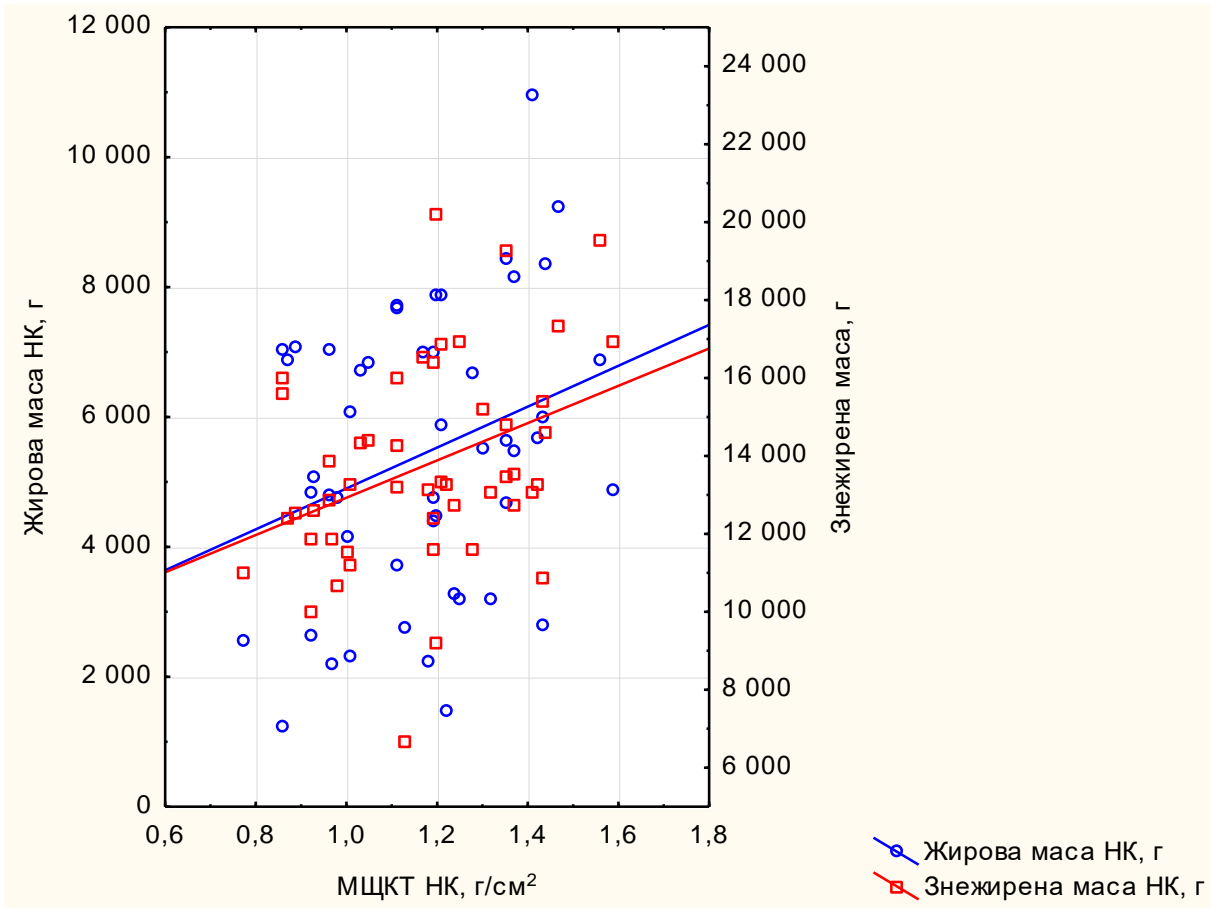

Рис. 4. Вплив жирової $і$ знежиреної маси нижніх кінцівок на МЩКТ нижніх кінцівок у пачієнтів із ТХСМ.

Примітка. НК - нижні кінцівки. Встановлено достовірний кореляційний зв'язок між показниками МЩКТ НК й знежиреною масою НК $(r=0,37 ; p<0,05)$ та МЩКТ НК НК й жировою масою НК $(r=0,29 ; p<0,05)$.

Обговорення результатів дослідження. Все частіше 3'являються нові роботи по вивченню впливу тілобудови на МЩКТ. Проте вплив окремих компонентів тілобудови на МЩКТ досі залишається не визначеним навіть у осіб без доведеної патології нервової чи м'язової системи. Відомо, що низька маса тіла є одним із факторів ризику розвитку остеопорозу, проте зустрічаються роботи, які повідомляють, що саме знежирена маса тіла має позитивний вплив на МЩКТ, тоді як дані про вплив жирової маси на МЩКТ залишаються суперечливими.

Згідно результатів бразильських науковців, які вивчали зв'язок жирової маси з МЩКТ всього тіла у молодих чоловіків залежно від IMT, встановлено вірогідний позитивний зв'язок жирової маси з МЩКТ всього тіла $(\mathrm{r}=0,475, \mathrm{p}<0,001)$, особливо у чоловіків з надмірною масою $(\mathrm{r}=0,65, \mathrm{p}<0,001)$. Проте, у чоловіків 3 нормальною масою тіла зв'язок виявився не достовірний $(\mathrm{r}=-0,18, \mathrm{p}=0,53)[8]$.

У дослідженні Kang DH. та співавт. встановлено позитивний вірогідний зв'язок МЩКТ 3 жировою та знежиреною масою тіла, а також індексом жирової та знежиреної маси $(\mathrm{p}<0,001)$ у чоловіків 3 нормальною масою тіла. Проте, у чоловіків 3 надлишковою масою тіла та ожирінням встановлено негативний вірогідний зв'язок між МЩКТ всього тіла та індексом жирової маси, а також відсотком жирової маси $(\mathrm{p}<0,05)$ [10].

В нашому дослідженні брали участь чоловіки 3 нормальною масою тіла, як в основній так і в групі порівняння (IMT 22,00 $\pm 2,86 ; 22,56 \pm 3,01$ відповідно), пацієнтів 3 надмірною масою тіла не було. Тобто коливання жирової маси в межах групи були незначними, що і обумовило відсутність зв’язків між показниками жирової маси та МЩКТ в нашому дослідженні, проте у пацієнтів із ТХСМ зареєстровано зв’язок між кістковою та жировою масою на рівні нижніх кінцівок.

У проспективному дослідженні проведеному Kim КМ та співавт. було вивчено зміни МЩКТ та знежиреної маси нижніх кінцівок у чоловіків та жінок з віком (період спостереження 5 років). У чоловіків МЩКТ на рівні стегнової кістки мала вірогідний зв'язок зі знежиреною масою нижніх кінцівок $(\mathrm{r}=0,21, \mathrm{p}<0,05)$. При проведенні багатофакторного аналізу встановлено незалежний позитивний зв'язок між зниженням сили нижніх кінцівок та втратою МЩКТ на рівні стегнової кістки у чоловіків $(\beta=0,023, \mathrm{p}<0,05)[11]$.

В нашому дослідженні не вивчались показники в динаміці, але встановлені вірогідні зв'язки між тривалістю посттравматичного періоду й знежиреною масою $(\mathrm{r}=-0,32 ; \mathrm{p}<0,05)$ та МЩКТ нижніх кінцівок $(\mathrm{r}=-0,40 ; \mathrm{p}<0,05)$, а також вірогідний зв'язок між показниками знежиреної маси $\mathrm{i}$ 
МЩКТ нижніх кінцівок $(\mathrm{r}=0,33 ; \mathrm{p}<0,05)$ дозволяють припустити, що втрата кісткової маси корелює з втратою м'язової маси, навіть у випадку повного випадіння функції м'язів.

Alonso A.C. та співавт. проаналізували показники тілобудови у чоловіків старшого віку 3 МЩКТ в межах вікової норми (Т-показник більший або рівний -1,0) та нормальним IMТ (від 18,5 до 29,5 кг/м²). В результаті проведеного дослідження встановлено вірогідний зв'язок між МЩКТ та показником знежиреної маси верхніх кінцівок $(\mathrm{r}=0,58, \mathrm{p} \leq 0,001)$, нижніх кінцівок $(\mathrm{r}$ $=0,47, \mathrm{p} \leq 0,001)$, тулуба $(\mathrm{r}=0,48, \mathrm{p} \leq 0,001)$ та всього тіла $(\mathrm{r}=0,53, \mathrm{p} \leq 0,001)$. Між МЩКТ та жировою масою верхніх кінцівок $(\mathrm{r}=0,43, \mathrm{p} \leq 0,001)$, нижніх кінцівок $(\mathrm{r}=0,35, \mathrm{p}=0,01)$, тулуба $(\mathrm{r}$ $=0,42, \mathrm{p} \leq 0,001)$ та всього тіла $(\mathrm{r}=0,44, \mathrm{p} \leq 0,001)$ також встановлено вірогідний зв'язок [12]. Наведені дані свідчать, що при нормальній кістковій тканині та нормальній масі тіла, МЩКТ залежить від знежиреної маси, отже, стани, які супроводжуються атрофічними процесами у м'язах можуть бути факторами ризику розвитку остеопорозу.

Після травми хребта та спинного мозку знежирена маса зменшується в ділянках, розташованих нижче зони ураження: на рівні нижніх кінцівок у пацієнтів з параплегією та на рівні верхніх, нижніх кінцівок і тулуба у пацієнтів з тетраплегією $[13,14]$. У випадку ТХСМ зменшення м'язової маси та МЩКТ відбуваються паралельно та під впливом одних і тих самих факторів, що обумовлює схожі темпи втрати м'язової та кісткової маси $[15,16]$.

\section{Висновки.}

1. У чоловіків із ТХСМ частота остеопорозу $(43,14 \%)$ та саркопенії $(84,31 \%) \epsilon$ достовірно вищою у порівнянні з практично здоровими особами (1,96\% та 25,49\% відповідно).

2. При ТХСМ реєструються достовірно нижчі показники знежиреної маси й апендикулярної знежиреної маси на рівні всього тіла, знежиреної маси на рівні тулуба й нижніх кінцівок, а вміст жирової маси є вірогідно вищим, як на рівні нижніх кінцівок, так і всього тіла.

3. Проведений кореляційний аналіз досліджуваних показників у практично здорових чоловіків виявив різнобічний вплив тілобудови на показники МЩКТ різного рівня нижніх кінцівок. Так, МЩКТ шийки стегнової кістки залежить від показника знежиреної маси верхніх кінцівок $(\mathrm{r}=0,33, \mathrm{p}<0,05)$, нижніх кінцівок $(\mathrm{r}=0,38, \mathrm{p}<0,05)$, тулуба $(\mathrm{r}=0,41, \mathrm{p}<0,05)$ та всього тіла $(\mathrm{r}=0,43, \mathrm{p}<0,05)$. На МЩКТ проксимального відділу стегнової кістки впливають показники знежиреної маси тулуба $(\mathrm{r}=0,36, \mathrm{p}<0,05)$ та всього тіла $(\mathrm{r}=0,34, \mathrm{p}<0,05)$. На МЩКТ нижніх кінцівок впливає знежирена маса тулуба $(\mathrm{r}=0,33, \mathrm{p}<0,05)$ та нижніх кінцівок $(\mathrm{r}=0,32, \mathrm{p}<0,05)$.

4. У чоловіків із ТХСМ спектр впливу тілобудови на МЩКТ шийки та проксимального відділу стегнової кістки є значно меншим. Так, МЩКТ шийки стегнової кістки корелює тільки 3 величиною знежиреної маси тулуба $(\mathrm{r}=0,30, \mathrm{p}<0,05)$, а проксимальний відділ стегнової кістки - 3 показниками знежиреної маси тулуба $(\mathrm{r}=0,31, \mathrm{p}<0,05)$ та знежиреної маси нижніх кінцівок $(\mathrm{r}=0,35, \mathrm{p}<0,05)$.

5. Як у практично здорових осіб, так і у чоловіків з ТХСМ на МЩКТ нижніх кінцівок впливають показники знежиреної маси тулуба $(\mathrm{r}=0,41, \mathrm{p}<0,05)$ та знежиреної маси нижніх

\section{ЛІТЕРАТУРА}

1. Carda S, Cisari C, Invernizzi M. Sarcopenia or muscle modifications in neurologic diseases: a lexical or patophysiological difference? Eur J Phys Rehabil Med.2013 Feb;49(1):119-30.

2. Clark JM, Findlay DM. Musculoskeletal health in the context of spinal cord injury. CurrOsteoporosRep.2017 Oct;15(5):433-442. doi: 10.1007/s11914-017-0400-1.

3. Поворознюк В. В., Дзерович Н. И. Саркопения и возраст: обзор литературы и результаты собственных исследований. Біль. Суглоби. Хребет. 2012.3 (07): 7-13

4. Dionyssiotis Y, Skarantavos G, Papaioannou N, Papagelopoulos P, Papathanasiou J, Lyritis G. Secondary sarcopenia in spinal cord injured subjects. Annals of Physical and Rehabilitation Medicine. 2018, Jul; 61, Suppl, Page e240.

5. Official Positions 2015 ISCD (Adult \& Pediatric). https://iscd.app.box.com/v/OP-ISCD-2015-Adult/. Accessed June 30, 2018.

6. Поворознюк В.В., Орлик Т.В., Крєслов С.О. Сучасний погляд на проблему остеопорозу у чоловіків в Україні. Біль. Суглоби. Хребет. 2012. 2 (06): 42-49.

7. Pelletier CA, Miyatani M, Giangregorio L, Craven BC. Sarcopenic obesity in adults with spinal cord injury: a cross-sectional study. Arch Phys Med Rehabil.2016 Nov;97(11):1931-1937. doi: https://doi.org/10.1016/j.apmr.2016.04.026

8. Bauman WA, Cardozo CP. Osteoporosis in individuals with spinal cord injury. PM\&R. 2015 Feb1;7(2):188-201. doi: 10.1016/j.pmrj.2014.08.948. 
9. Rodrigues Filho EA, Moura dos Santos MA, Pereira da Silva AT, Farah BQ, Costa MC, Campos FA, Tavares Falcão AP. Relation between body composition and bone mineral density in young undergraduate students with different nutritional status. Einstein. 2016;14(1):12-7. DOI: 10.1590/S167945082016AO3569.

10. Kang DH, Guo LF, Guo T, Wang Y, Liu T, Feng XY, et al. Association of body composition with bone mineral density in northern Chinese men by different criteria for obesity. J EndocrinolInvest. 2015;38(3):323-31.

11. Kim KM, Lim S, Oh TJ, Moon JH, Choi SH, Lim JY, Kim KW, Park KS, Jang HC. Longitudinal changes in muscle mass and strength, and bone mass in older adults: gender-specific associations between muscle and bone losses. J Gerontol A Biol Sc Med Sci. 2018 Jul 9;73(8):1062-1069. doi: 10.1093/gerona/glx188.

12. Alonso AC, Gonçalves TA, Almeida JKA, Machado-Lima A, Ernandes RC, Greve JMD, Garcez-Leme LE. Relationship between bone mineral density and body composition in elderly. Acta Ortop Bras. 2018; 26(1):27-9. DOI: http://dx.doi.org/10.1590/1413-785220182601182340.

13. Gorgey A, Dolbow D, Dolbow J, Khalil R, Castillo C, GaterD. Effects of spinal cord injury on body composition and metabolic profile - Part I //J Spinal Cord Med. November, 2014; 37(6): 693-702. doi:10.1179/2045772314Y.0000000245

14. Park AJ, Battaglino RA, Nguyen NMH, Morse LR. Associations between lean mass and leptin in men with chronic spinal cord injury: Results from the FRASCI-muscle study. PLoS One. 2018 Jun 27;13(6): e0198969. doi: 10.1371/journal.pone.0198969.

15. Dionyssiotis Y, Lyritis GP, Mavrogenis AF, Papagelopoulos PJ. Factors influencing bone loss in paraplegia// Hippokratia. 2011 Jan-Mar; 15(1): 54-59.

16. Qin W, Bauman WA, Cardozo C Bone and muscle loss after spinal cord injury: organ interactions. Ann NY Acad Sci. 2010 Nov; 1211: 66-84. doi: 10.1111/j.1749-6632.2010.05806.x.

17. Gorgey AS, Martin H, Metz A, Khalil RE, Dolbow DR, Gater DR. Longitudinal changes in body composition and metabolic profile between exercise clinical trials in men with chronic spinal cord injury. $\mathrm{J}$ Spinal Cord Med. 2016 Nov; 39(6): 699-712. doi: 10.1080/10790268.2016.1157970 